\section{SOI: $1.1 /$ TAS DOI: $10.15863 /$ TAS International Scientific Journal Theoretical \& Applied Science}

p-ISSN: 2308-4944 (print) e-ISSN: 2409-0085 (online)

Year: 2017 Issue: 04 Volume: 48
Khushvakt Saparbayevich Khayitov

Senior scientific researcher, $\mathrm{PhD}$,

Academy of State Governance under the President of the Republic of Uzbekistan,

Published: $30.04 .2017 \quad$ http://T-Science.org

SECTION 29. Literature. Folklore. Translation Studies.

\title{
LEGAL LINGUISTIC EXPERTISE OF DRAFT LAWS: THEORETICAL- LEGAL ANALYSIS
}

Abstract: This article analyzes the necessity of conducting legal linguistic expertise of draft laws and considers its scientific and legal bases, peculiarities of legal linguistic expertise in some foreign countries. In addition, some recommendations on improvement of the practice have been suggested.

Key words: legal linguistics, expertise, lawmaking, legal linguistic expertise, mechanism of carrying out legal linguistic expertise.

Language: English

Citation: Khayitov KS (2017) LEGAL LINGUISTIC EXPERTISE OF DRAFT LAWS: THEORETICALLEGAL ANALYSIS. ISJ Theoretical \& Applied Science, 04 (48): 154-157.

Soi: http://s-o-i.org/1.1/TAS-04-48-25 Doi: crossef https://dx.doi.org/10.15863/TAS.2017.04.48.25

\section{Introduction.}

Any law, as a normative legal act, is considered to be a product of a legal language. The content of a law is expressed through the legal language. Therefore, in order to ensure the quality of the language it is required to strictly adhere to linguistic rules.

However, this is not always easily achieved. Naturally, employing a difficult style of the legal language and terminology creates certain difficulties for the legislator. In this regard, the significance of conducting legal linguistic expertise of draft laws is great.

It should be noted that this type of expertise bears bilateral scientific basis. To make it clear, experts who are engaged with conducting this kind of expertise should have both legal and linguistic knowledge. Only in this case, they can perform professional expertise of draft laws, meeting both legal and linguistic requirements. It is worth saying that Legal linguistics as interdisciplinary direction is widely studied as a separate object of study.

\section{Materials and Methods}

It is appropriate here to refer to scientific foundations of this expertise. Currently, there is a growing need for in-depth exploration of Legal linguistics as an interdisciplinary study. In the world practice, a new direction of interdisciplinary studies - "law and language" appeared in the second half of 70s of XX century, and primarily developed in the United States and Western Europe.

In 1978 in Uppsala a working group of sociologists "Language of law application practice" was organized by the World Congress [1]. Since then, on this issue, prestigious national and international journals have been released and monographs, dozens of articles in legal linguistic periodicals have been published [2].

If we refer to the experience of Germany, a discipline "Rechtslingwistik" ("Legal Linguistics") deals with issues of the language and laws. This term was first used by Adelbert Podlech in 1976. He called a "set of all methods and results of studies concerning relationship between a language and a law and conforming to the requirements of modern Linguistics" as "Legal Linguistics"[3]. As the experience of this country indicates, contemporary interpretation of legal linguistics has grown considerably and modern linguistics requirements have noticeably changed. In this regard, a correlation between law and Linguistics in the study of language issues in law has changed and the role of linguistic research has increased in this field [4]. Researchers of Heidelberg scientific group on Legal Linguistics define this sphere that it is based on interconnectedness of interpretation in the jurisprudence and language analysis as a "practical" scientific-theoretical semantics and current practical sphere[5]. 
Professor N.Golev, who conducts special research in this sphere, calls an area of science studying "law and language", as "Juridical Language". He notes that the object of the study includes a correlation between a language and a law and he points out that a juridical language studies legal aspects of the language, and linguistics of law studies aspects of the law relating to the language[6].

Law scholars emphasize the necessity of learning "Legal Language" as a field of literary language, which reflects law. It is mentioned that this thought has its solid foundation.

In particular, law scholars H.Odilkoriev and I.Tulteyev argue that "peculiarities of texts of normative acts allow drawing a conclusion about the existence of a special legal language. A large number of legal terms require special knowledge or interpretations. Features of law texts provide reasonable evidence of existence of the special language of legal acts"[7].

Upon thinking about a legal language, GerardRené de Pile, Professor of Comparative and Private International Law at Dutch University of Maastricht, said that relationship between "law and language" is observed in statutes (the name of Acts), judicial decisions. It would be difficult to imagine a modern society without written legal texts. Legal language features define what words of a precise legal construction should be exactly used in the process of formation of legal norms of statutes or warn what words to use[8].

Based on above-mentioned, it may be observed that the language of law does not mean there is a new language in society. On the contrary, it turns out to be an integral part of literary language. In my view, Legal Linguistics is a complex of theoretical rules, knowledge of Linguistics and Law used in reflection of content and features of law.

Based on such knowledge the expertise is advised to be referred to as legal linguistic expertise. Through legal linguistic expertise it is meant an examination which is drawn up in the form of conclusive decision made by legally and linguistically knowledgeable specialist or specialists to assess the quality of draft laws. Law Scholar B.Abdullayev specifies with regard to this expertise that: "Juridical language expertise of draft laws consists of assessing conformity of represented text to norms of modern literary language, taking into account functional and stylistic peculiarities of texts of laws"[9].

Errors in law text structure and other stylistic, lexical, and grammatical errors are eliminated through implementation of the legal linguistic expertise of draft laws. The more perfect law texts are, the easier they are applied.

It is necessary here to dwell on expertise classification. According to Law Scholar H.Odilkoriev, one can distinguish informal and formal forms of linguistic expertise of draft laws[10]. In his view, work on drafting a text of laws is performed by a subject initiating the law or on his behalf by experts, academic institutions, ministries and other organizations. Specialists, scientists can take part in preparation of the draft law and carry out peer review of the initial draft during this period. Furthermore, after introduction of the draft law in the lower chamber of the parliament, the expertise arranged by a standing committee and exercised in the manner provided by the law is considered official expertise of draft laws.

In my view, conducting legal linguistic expertise of draft laws can be classified on several grounds:

Firstly, on lawmaking stages;

Secondly, on lawmaking subjects;

Thirdly, on lawmaking scope.

The following kinds of carrying out legal linguistic expertise can be highlighted according to the following lawmaking stages: at the stage of initiating a law; at the stage of parliamentary consideration of draft laws; at the stage of signing a law by the President.

Based on subjects dealing with lawmaking activity, legal linguistic expertise can be implemented at the following stages:

When realizing a law initiative the legal linguistic expertise is carried out by a responsible body. For instance, it can be conducted on the initiative of bodies of law initiative such as the Cabinet of Ministers, the Supreme Court;

during consideration of the law by the Legislative Chamber of the Oliy Majlis upon the request of directly interested structure or on the initiative of standing committees of the parliamentary house;

During consideration of the law by the Senate of the Oliy Majlis on the initiative of the Senate;

During submission of a law to the President for signature on the initiative of the President.

According to the scope of the content of draft laws the expertise can be conducted over the whole text of draft laws or over a certain part of the text, article.

Legal linguistic expertise is a multifaceted and complicated process and while analyzing a draft law, deep knowledge of a particular field of Law and Linguistics is required from an expert. In short, in preparation of expert opinions an expert has to be highly qualified.

Assuming that the object of this task is characterized by two aspects, the most effective method consists in its realization by Law specialists and linguists, as well as experts who are knowledgeable about these areas.

Legal linguistic expertise must meet the following primary requirements: 
Firstly, the purpose of expertise must be directed at assessment of compliance of draft law text with literal language rules;

Secondly, it must be directed at provision of compliance of the text with a language of normative legal documentation (legislative technique);

Thirdly, experts must have legal knowledge as well as linguistic one;

Fourthly, independence and objectivity of the activity of the expert must be provided.

If we refer to the experience of foreign countries, in the Russian Federation there is noteworthy experience in conducting this expertise. Despite the fact that the Legal Department of the Russian State Duma carries out legal linguistic expertise of draft laws, in 1994 in the structure of this department a special sub department was created to conduct legal linguistic expertise of draft laws. The main objective and functions of the sub department are to conduct legal linguistic expertise of constitutional, federal draft laws, resolutions, declarations, appeals adopted by the State Duma, and offer methodological assistance to the Parliament in unification of the language of legislation, improvement of its formalization. Pursuant to Article 102 of the Rules of the State Duma, following the first reading of draft laws on the initiative of a standing committee legal linguistic or other expertise of the draft law may be assigned [11].

If we turn to the experience of Germany, draft laws of the Federal Government are, first of all, forwarded to the Federal Ministry of Justice in order to obtain permission of the interested ministry and determine their conformity with the current legislation and legislation techniques. The Federal Ministry of Justice carries out an expert examination over the language of law and legislation techniques [12].

The Federal Ministry of Justice is empowered to examine compliance of the law with the current laws in terms of its language. In order to ensure "a single language of laws" a preliminary examination over formalization of draft laws is made by the Ministry of Justice.

Legal linguistic expertise of draft laws under consideration in the Bundestag is exercised by the Language Service. The Language Service implements the following in this regard the important tasks: translation and interpreting services; holds language lessons; plays an important role in the development of parliamentary vocabulary [13].
In the legislation of Uzbekistan, some strict requirements for conducting expertise of draft laws are also determined. In particular, pursuant to Article 21 of the Law of the Republic of Uzbekistan "On Normative Legal Acts", draft normative legal acts must go through legal expertise. In addition, draft normative legal acts may be subject to economic, financial, scientific, environmental and other kinds of expertise on decision of a developer or body adopting a normative legal act [14].

Today the legal linguistic expertise of draft laws is done along with legal expertise. In my opinion, draft laws should be subject to legal linguistic expertise in a particular order. Only in this case, such conditions will be created that every term of a draft law will be carefully scrutinized and any shortcoming concerning a language will be eliminated.

According to Article 23 of the Law of the Republic of Uzbekistan "On the Order of Preparation of Draft Laws and Their Submission to the Legislative Chamber of the Oliy Majlis of the Republic of Uzbekistan", proposals made while discussing and opinions expressed in conclusions of experts hold a recommendatory character [15]. Moreover, undoubtedly, this expertise is important in drafting laws in an accurate and understandable language.

\section{Conclusion}

In conclusion, it can be noted that legal linguistic expertise is a many-sided and complex process, and when carrying out expertise of draft laws it is required from an expert to know certain areas of Law and be theoretically linguistically knowledgeable. Therefore, the most effective solution to this problem is a joint fulfillment of the expertise by lawyers and expert linguists.

In addition, as it is known from lawmaking practice of some foreign countries, special attention is paid to the legal linguistic expertise of draft laws while developing and adopting draft laws and simultaneously, there are institutions specialized in the expertise of draft laws from a language point of view. These institutions have made a great contribution to the formation of comprehensively perfect legal language. In this regard, it is important to establish a special structure in the parliament that provides legal linguistic expertise services.

\section{References:}




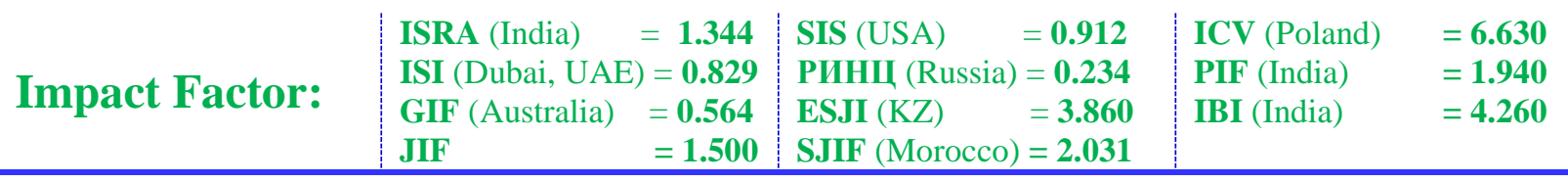

1. See Berteloot Pascale. Der Rahmen JurischerÜbersetyungen // de Groot, GerardRene; Schulze, Reiner [Hrsg.]. Recht undbbersetzen-Baden- Baden: Nomos, 1999. 101-113 p.

2. See Dietrich Rainer Klien, Wolfgang etalii (Berliner Arbeitsgruppe). Sprache des Rechts.Vermitteln, Vestehen, Verwechseln // Zeitschrift für Literaturwissenschaft und Linguistik. Sprache des Rechts. Heft 118, 2000. $-5-33$ p.

3. See Podlech Adalbert. Rechtslinguistik // Grimm, Dieter [Hrsg.]. Rechtswissenschaft und Nachbarwissenschaft. Bd. II, München: Beck, 1976. 105-116 p.

4. See Busse Dietrich. Recht als Text. Linguistische Untersuchungen zur Arbeit mit Sprache in einer gesellschaftichen Institution. Tьbingen Niemezer, 1992. 11-12 p.

5. See Müller Friendrich [Hrsg.]. Untersuchungen zur Rechtslingustik. Interdisziplinäre Studien zu prakzischer Semantik und Strukturierender Rechtslehre in Grundlagen der juristischen Mezodik. Berlin: Duncker \& Humblot, 2001. 44-57 p.

6. Golev N.Legal aspectsof legal interpretation., University of Altai, 1999. 12 p.

7. Odilkoriyev X.,Tulteyev I. Bicameral parliament. 2-нашр. - Tashkent: Academy of MIA of the Republic of Uzbekistan, 2005. 196 p.

8. Gerard Rene de Groot Language and law.-S., http://www.library.uu.nl/publarchief/jb/congres , 1997. $1 \mathrm{p}$.
9. Abdullayev B. Legal linguistic expertise: basis of perfectness of laws // Law and Duty. - 2008. №11. 40 p.

10. Odilkoriyev X. Improvement of scientific-legal expertise of draft laws // "Challenges of expertise of legislative acts". Materials of scientific-practical seminar / Chief editor: F.Otaxonov. - Tashkent: 2005. 27 p.

11. See Kalinina N. Linguistic expertise of legislation: practice, challenges, perspectives(In the example of the work of the Legal Department of the Office of the State Duma of the Federal Assembly of the Russian Federation):Scientific and practical manual / Legal Department of Apparatus of the State. Duma of the Federal Assembly-Parliament of the Russian Federation. - Moscow: Publishing House of the State Duma: Izvestiya, 1997. 41$44 \mathrm{p}$.

12. See Handbook of lawmakingtechnique /Handbuch der Rechtsformlichkeit. - M., Bek, 2002. 296 p.

13. See Rupert Shik and Volfgang Tse. This is how the Bundestag works (14-convocation) Organization, forms and methods of work of Legislation of the Federation - NDV Neue Dermstadter Verlagsanstalt Rheinbreitbach, 2000. 78 p.

14. Collection of legislative acts of the Republic of Uzbekistan, 2012, №52, article 583; 2014, №50, article 588; 2015, № 32, article 425; 2016, №39, article 457 .

15. Collection of legislative acts of the Republic of Uzbekistan, 2006, №41, article 406. 